\title{
Titanium Complex Containing a Saligenin Ligand - New Universal Post-Metallocene Polymerization Catalyst: Copolymerization of Ethylene with Higher $\alpha$-Olefins
}

\author{
Laura A. Rishina ${ }^{1, *}$, Svetlana S. Lalayan ${ }^{1}$, Svetlana Ch. Gagieva ${ }^{2}$, Vladislav A. Tuskaev², \\ Alexander N. Shchegolikhin ${ }^{3}$, Dimitri P. Shashkin ${ }^{1}$ and Yury V. Kissin ${ }^{4}$ \\ ${ }^{1}$ Semenov Institute of Chemical Physics, Russian Academy of Sciences, 4 Kosygin St., Moscow, 119991, \\ Russia \\ ${ }^{2}$ Moscow State University, Department of Chemistry, Leninskie Gory, Moscow, 119992, Russia \\ ${ }^{3}$ Emanuel Institute of Biochemical Physics, Russian Academy of Sciences, 4 Kosygin St., Moscow, 119991 , \\ Russia \\ ${ }^{4}$ Rutgers, The State University of New Jersey, Department of Chemistry and Chemical Biology, \\ 610 Taylor Rd., Piscataway, NJ 08854, USA
}

\begin{abstract}
Copolymerization reactions of ethylene with three a-olefins, 1-hexene, 1-octene and 1-decene, were carried out with a new post-metallocene catalyst based on Ti complex with a bidentate saligenin-type ligand $\mathbf{I}$ and two co catalysts, $\mathrm{MAO}$ and a combination of $\mathrm{AlEt}_{2} \mathrm{Cl}$ and $\mathrm{MgBu}_{2}$. Ability of the I - $\mathrm{AlEt}_{2} \mathrm{Cl}-\mathrm{MgBu}_{2}$ system to copolymerize $\alpha-$ olefins with ethylene is far superior to that of the I - MAO system. Reactivity of a-olefins in copolymerization reactions with ethylene decreases in the sequence: 1-hexene>1-octene>1-decene. Both catalyst systems, I - MAO and I- $\mathrm{AlEt} \mathrm{t}_{2} \mathrm{Cl}$ $\mathrm{MgBu}_{2}$, contain several populations of active centers that greatly differs both in the average molecular weights and in composition of the copolymer molecules they produce. Active centers in both catalytic systems show significant tendency to alternate monomer units in copolymer chains.
\end{abstract}

Keywords: Post-metallocene catalysts, molecular weight distribution, compositional distribution, differential scanning calorimetry, nuclear magnetic resonance.

\section{INTRODUCTION}

Copolymers of ethylene and linear higher a-olefins are widely used in industry as general-purpose and specialty plastics in film and container applications [1, 2]. They are usually synthesized using heterogeneous Ziegler-Natta and metallocene-based catalysts. At the present time, the point of attention in alkene polymerization chemistry has shifted to postmetallocene catalysts based on a variety of multidentate complexes of transition metals [3-8]. Similar to metallocene catalysis, post-metallocene catalysts also afford the control of the chain microstructure, copolymer homogeneity and morphology through the choice of the multidentate ligands and polymerization conditions. One of the advantages of many postmetallocene catalysts compared to metallocene catalysts is relative affordability and simplicity of their synthesis. We have found earlier that a titanium complex $\angle \mathrm{TiCl}_{2} \cdot \cdot \mathrm{MgCl}_{2}$ containing a saligenin ligand, $\{2-$

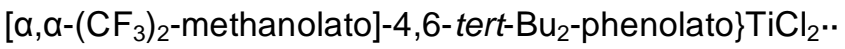
$\mathrm{MgCl}_{2}$ (I) is an effective catalyst for polymerization of propylene to a moderately isotactic polymer [9].

${ }^{*}$ Address correspondence to this author at the Semenov Institute of Chemical Physics, Russian Academy of Sciences, 4 Kosygin St., Moscow, 119991, Russia; Tel: 7495 9397379; E-mail: rishina@polymer.chph.ras.ru

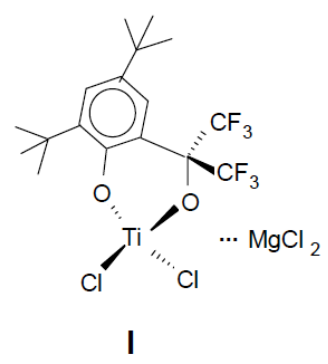

Here we present the results of our investigation in which complex I was employed as a catalyst for copolymerization of ethylene with three linear a-olefins, 1-hexene, 1-octene and 1-decene. Two organometallic cocatalysts were used to activate I, polymethylalumoxane (MAO) and a combination of $\mathrm{AlEt}_{2} \mathrm{Cl}$ and $\mathrm{MgBu}_{2}$ at an $[\mathrm{Al}] /[\mathrm{Mg}]$ molar ratio of $\geq 3$. The efficiency of the latter binary cocatalyst in polymerization reactions of ethylene and various a-olefins with different types of transition metal catalysts was described earlier [9-12].

\section{EXPERIMENTAL}

\subsection{Materials}

The source of the bidentate ligand $L$ in $\mathbf{I}$, oxyphenol 2,4-tert-Bu -6 - $\left(1,1,1,3,3,3-\mathrm{F}_{6}\right.$-oxypropan-2-yl)phenol, 
was prepared from hexafluoroacetone and 2,4-di-tertbutylphenol as described in [13].

\section{Complex I}

A two-necked flask equipped with a magnetic stirrer was loaded with toluene $(10 \mathrm{ml})$ and the oxyphenol $(0.19 \mathrm{~g}, 0.50 \mathrm{mmol})$ under argon flow and the solution was cooled to $-78{ }^{\circ} \mathrm{C} . \mathrm{MgBu}_{2}(1 \mathrm{M}$ solution in $n$ heptane, $1 \mathrm{ml}$ ) was added drop-wise and the mixture was slowly heated to $20{ }^{\circ} \mathrm{C}$ and kept at $20^{\circ} \mathrm{C}$ for 4 hours under stirring. Then the temperature was again decreased to $-78{ }^{\circ} \mathrm{C}$, neat $\mathrm{TiCl}_{4}(0.055 \mathrm{ml}, 0.50 \mathrm{mmol})$ was added to the mixture and the temperature was increased to $20^{\circ} \mathrm{C}$ causing precipitation of I. Complex I was repeatedly crystallized from toluene and dried under vacuum at $30^{\circ} \mathrm{C}$.

For $\mathrm{C}_{17} \mathrm{H}_{20} \mathrm{Cl}_{2} \mathrm{~F}_{6} \mathrm{O}_{2} \mathrm{Ti}$ calculated (\%): C, 41.75; $\mathrm{H}, 4.12$; $\mathrm{Cl}, 14.50 ; \mathrm{Ti}, 9.79$.

found (\%): C, 41.69; H, 5.09; Cl, 14.65; Ti, 9.67.

${ }^{1} \mathrm{H}$ NMR (toluene- $\mathrm{d}_{8}$ ), ppm: $7.89(\mathrm{~s}, 1 \mathrm{H}) ; 7.52(\mathrm{~d}, 1 \mathrm{H}$, $J=2.2 \mathrm{~Hz}) ; 1.46(\mathrm{~s}, 9 \mathrm{H}) ; 1.27(\mathrm{~s}, 9 \mathrm{H})$.

In the current research, complex I was used in polymerization reactions without separating it from the byproduct $\mathrm{MgCl}_{2}$, as suspension in toluene.

\section{Cocatalysts}

MAO was purchased from Witco as $10 \%$ solution in toluene. $\mathrm{AlEt}_{2} \mathrm{Cl}$ and $\mathrm{MgBu}_{2}$ were purchased from Acros as $0.8 \mathrm{M}$ and $0.5 \mathrm{M}$ solutions in heptane, respectively.

Toluene (analytic grade) was boiled over $\mathrm{Na}$ and distilled in argon flow. 1-Hexene, 1-octene and 1-decene were also distilled over $\mathrm{Na}$. Ethylene (polymerization grade, 99.9\%) was purchased from the Moscow Oil Refining Plant and was used as received.

\subsection{Copolymerization Reactions}

Copolymerization reactions of ethylene and the a-olefins were carried out at $50{ }^{\circ} \mathrm{C}$ in a stainless steel reactor equipped with a stirrer. The reactions were conducted in a toluene medium at the ethylene partial pressure $\left(P_{\mathrm{E}}\right)$ of 3.8 atm and the ethylene concentration in solution $\left(C_{\mathrm{E}}\right)$ of $\sim 0.37 \mathrm{M}$. The reactor was kept under vacuum for one hour and then toluene, an $\alpha$-olefin and a cocatalyst were introduced into it. When the binary $\mathrm{AlEt}_{2} \mathrm{Cl}-\mathrm{MgBu}_{2}$ cocatalyst was used, its components were added to the reactor one after another. The reaction mixture was saturated with ethylene and then a sealed glass ampule with I suspension was broken inside the reactor. The $P_{\mathrm{E}}$ was kept constant throughout each run; the ethylene loss in the reactor was compensated for by adding additional

Table 1: Copolymerization of Ethylene and Linear $\alpha$-Olefins with Complex I

\begin{tabular}{|c|c|c|c|c|c|c|c|c|c|}
\hline \multirow[t]{2}{*}{ Run } & \multirow[t]{2}{*}{ a-Olefin } & \multicolumn{2}{|c|}{ Monomer mixture } & \multicolumn{3}{|c|}{ Catalyst system } & \multirow{2}{*}{$\begin{array}{c}\text { Ethylene } \\
\text { consumption, } \\
\mathrm{kg} \cdot \mathrm{mol}_{\mathrm{Ti}}^{-1}\end{array}$} & \multicolumn{2}{|c|}{ Copolymer } \\
\hline & & $C_{\mathrm{M}}{ }^{\text {mon }}, \mathrm{M}$ & $\begin{array}{c}\text { a-olefin, } \\
\text { mol. fraction }\end{array}$ & $\underset{M}{[\mathrm{Ti}] \cdot 10^{5}}$, & $\begin{array}{l}{[\mathrm{Al}] /[\mathrm{Ti}]} \\
\mathrm{mol} / \mathrm{mol}\end{array}$ & $\begin{array}{c}{[\mathrm{Al}] /[\mathrm{Mg}]} \\
\mathrm{mol} / \mathrm{mol}\end{array}$ & & $\begin{array}{c}\text { Yield, } \\
\mathrm{kg} \cdot \mathrm{mol}_{\mathrm{Ti}}^{-1}\end{array}$ & $\begin{array}{l}C_{\mathrm{M}}{ }^{\text {copol }} \text {, } \\
\text { mol. \% }\end{array}$ \\
\hline \multicolumn{10}{|c|}{ Cocatalyst MAO } \\
\hline $1-\mathrm{A}$ & - & - & - & 1.79 & 410 & - & 732 & 735 & 0 \\
\hline $2-A$ & 1-Hexene & 0.24 & 0.39 & 2.02 & 440 & - & 842 & 850 & 0.3 \\
\hline $3-A$ & 1-Hexene & 1.6 & 0.81 & 2.27 & 460 & - & 552 & 696 & $8.0-9.0$ \\
\hline $4-A$ & 1-Octene & 0.26 & 0.41 & 2.16 & 410 & - & 1092 & 1010 & - \\
\hline $5-A$ & 1-Decene & 0.26 & 0.41 & 1.94 & 460 & - & 903 & 902 & 0.4 \\
\hline $6-A$ & 1-Decene & 1.7 & 0.82 & 1.61 & 460 & - & 1230 & 1233 & 0.7 \\
\hline \multicolumn{10}{|c|}{ Cocatalyst $\mathrm{AlEt}_{2} \mathrm{Cl}-\mathrm{MgBu}_{2}$} \\
\hline $1-B$ & - & - & 0 & 0.66 & 340 & 3.0 & 1727 & 1720 & 0 \\
\hline $2-B$ & 1-Hexene & 0.24 & 039 & 0.66 & 340 & 3.0 & 1560 & 1666 & $3.5-4.0$ \\
\hline $3-B$ & 1-Hexene & 1.6 & 0.81 & 1.02 & 320 & 3.4 & 2098 & 2843 & $12.0-13.0$ \\
\hline $4-B$ & 1-Hexene & 4.4 & 0.92 & 0.75 & 360 & 3.2 & 1866 & 4266 & $20.0-22.0$ \\
\hline $5-B$ & 1-Octene & 0.26 & 0.41 & 0.62 & 360 & 3.2 & 1742 & 1774 & 1.7 \\
\hline $6-B$ & 1-Octene & 1.7 & 0.82 & 0.77 & 350 & 3.2 & 2260 & 3545 & $9.0-10.0$ \\
\hline $7-B$ & 1-Decene & 0.26 & 0.41 & 0.75 & 360 & 3.2 & 1340 & 1400 & 1.3 \\
\hline $8-B$ & 1-Decene & 1.7 & 0.82 & 0.82 & 330 & 3.2 & 2061 & 3292 & $8.0-9.0$ \\
\hline
\end{tabular}

${ }^{1}$ Reaction temperature $50^{\circ} \mathrm{C}, P_{\mathrm{E}}=3.8$ atm, $C_{\mathrm{E}}=0.37 \mathrm{M}$. 
gas from a high-pressure vessel. The amount of consumed ethylene was calculated from the pressure drop in the vessel. The produced copolymers were treated with a mixture of ethanol and $10 \% \mathrm{HCl}$, then they were washed with water and ethanol and dried under vacuum at $60^{\circ} \mathrm{C}$ to a constant weight.

All the reaction conditions and the results of the experiments are given in Table 1. Catalyst activity is presented as a polymer yield with respect to one mole of $\mathrm{Ti}\left(\mathrm{kg} \cdot \mathrm{mol}_{\mathrm{T}}^{-1}\right)$; the effective rate constant $k_{\mathrm{eff}}$ was calculated as $R \cdot\left(C_{\mathrm{E}} \cdot C_{\mathrm{T}_{\mathrm{I}}}\right)^{-1}\left(\mathrm{I} \cdot \mathrm{mol}_{\mathrm{T}}^{-1} \cdot \mathrm{min}^{-1}\right)$ where $R$ is the reaction rate $\left(\mathrm{M} \cdot \mathrm{min}^{-1}\right)$, and $C_{\mathrm{E}}$ and $C_{\mathrm{Ti}}$ are the concentrations of ethylene and $\mathbf{I}$.

\subsection{Polymer Characterization}

IR spectra of the copolymers (thin films) were recorded on the Perkin-Elmer FTIR spectrophotometer. ${ }^{13} \mathrm{C}$ NMR spectra of the copolymers ( $\sim \mathrm{wt}$. \% solutions in o-dichlorobenzene) were recorded at $100{ }^{\circ} \mathrm{C}$ on a Bruker Avance-400 spectrometer at $10.613 \mathrm{MHz}$. The relaxation delay was $15 \mathrm{~s}$, the number of scans varied from 500 to 2000 . The signal assignment was based on the literature data [14].

The content of a-olefins in copolymers $\left(C_{\mathrm{M}}{ }^{\text {copol }}\right.$, mol. \%) was calculated from the IR data, (from $A_{1380} / A_{1368}$ and $A_{1380} / A_{722}$ absorbance ratios) using the calibration curve in [15] and from ${ }^{13} \mathrm{C}$ NMR. In addition, copolymer compositions were determined from differences between the copolymer yields and ethylene consumption in particular runs.

GPC analysis of the polymer samples was carried out with a Waters GPCV-2000 chromatograph equipped with two columns (PL-gel, $5 \mu$ и Mixed-C, $300 \times 7.5 \mathrm{~mm}$ ) and a refractometer. The analysis was performed at $135^{\circ} \mathrm{C}$ using $1,2,4$-trichlorobenzene as a solvent, the elution rate was $1 \mathrm{ml} \cdot \mathrm{min}^{-1}$. The separation procedure of GPC curves into the curves of individual polymer components (Flory components, the material produced by a single type of active center) was described earlier [16].

Melting curves of copolymers (3-5 mg) were measured by the DSC method on a Perkin-Elmer DSC7 analyzer at two heating rates, 2 and $10^{\circ} \mathrm{C} \cdot \mathrm{min}^{-1}$. The data on the second melting of the samples, after slow crystallization from $140{ }^{\circ} \mathrm{C}$ at a $0.5^{\circ} \mathrm{C} \cdot \mathrm{min}^{-1}$ rate, were examined.

X-ray diffractograms of the polymers were measured on a Dron-2 diffractometer (Ni-filtered CuK $K_{\alpha}$ radiation) at a scanning rate of $1^{\circ}(2 \theta) \cdot \mathrm{min}^{-1}$. The crystallinity degree of the copolymers was determined from the ratio of the integral intensity of the crystalline component and the overall signal intensity.

\section{EXPERIMENTAL RESULTS}

\subsection{Copolymer Synthesis}

Table 1 gives experimental conditions of the copolymer synthesis and the principal polymerization results. Table 2 lists main physical properties of the produced materials. When MAO was used as a cocatalyst, the yield of the ethylene homopolymer (run 1-A) was $\sim 735 \mathrm{~kg} \cdot \mathrm{mol}_{\mathrm{Ti}}^{-1}$, the value which practically coincided with the ethylene consumption in the experiment. Addition of $\alpha$-olefins to the reactor in the majority of experiments except for the 3-A run resulted in a $\sim 15-70 \%$ increase of the polymer yield. However, the a-olefin content in most of these products was very low, from 0.3 to $0.7 \mathrm{~mol}$. \% ( ${ }^{13} \mathrm{C} N M R$ data). A copolymer with a relatively high content of an a-olefin, $\sim 8 \mathrm{~mol}$. \%, was produced only in one experiment (run 3-A) when the 1-hexene content in the olefin mixture was $>80 \mathrm{~mol}$. \%. Judging by the depressed melting point of these products and their lower crystallinity degree, there are true ethylene/ $\alpha$-olefin copolymers.

The "comonomer effect", an increase of activity in catalytic polymerization reactions of ethylene caused by addition of $\alpha$-olefins, is well known both for Ti-based heterogeneous Ziegler-Natta catalysts and for metallocene catalysts [17-19]. Two alternative explanations are usually proposed. The first explanation is based on a purely mechanical effect: polymer molecules surrounding the active centers can create a diffusion barrier for ethylene and this barrier can be lower in the case of copolymers which have a lower crystallinity degree. An alternative explanation proposes a chemical cause for the comonomer effect $[17,20,21]$. The rate constant $k^{\prime}$ for ethylene insertion into an active center at each step of chain initiation, the $>\mathrm{Ti}-\mathrm{CH}_{2}-\mathrm{CH}_{3}$ species,

$>\mathrm{Ti}-\mathrm{CH}_{2}-\mathrm{CH}_{3}+\mathrm{CH}_{2}=\mathrm{CH}_{2}-\left(k^{\prime}\right) \rightarrow$

$>\mathrm{Ti}-\mathrm{CH}_{2}-\mathrm{CH}_{2}-\mathrm{CH}_{2}-\mathrm{CH}_{3}$

is lower in comparison with the rate constant $k^{\prime \prime}$ for ethylene insertion into an active center in all subsequent steps of chain growth, ethylene insertion into active centers carrying polymer chains,

$>\mathrm{Ti}-\left(\mathrm{CH}_{2}-\mathrm{CH}_{2}\right)_{\mathrm{n}}-\mathrm{CH}_{2}-\mathrm{CH}_{3}+\mathrm{CH}_{2}=\mathrm{CH}_{2}-\left(k^{\prime \prime}\right) \rightarrow$

$>\mathrm{Ti}-\left(\mathrm{CH}_{2}-\mathrm{CH}_{2}\right)_{\mathrm{n}+1}-\mathrm{CH}_{2}-\mathrm{CH}_{3}$ 
Table 2: Molecular Weights and Properties of Ethylene/a-Olefin Copolymers

\begin{tabular}{|c|c|c|c|c|c|c|}
\hline $\begin{array}{c}\text { Run, } \\
\text { a-olefin }\end{array}$ & $\begin{array}{l}C_{\mathrm{M}}{ }^{\text {copol }} \\
\text { mol. } \%\end{array}$ & $M_{\mathrm{w}} \cdot 10^{-3}$ & $M_{\mathrm{w}} / M_{\mathrm{n}}$ & $T_{\mathrm{m}},{ }^{\circ} \mathrm{C}^{1}$ & $\Delta H_{\text {fusion, }}, \mathrm{J} \cdot \mathrm{g}^{-1}$ & $\begin{array}{c}\text { Crystallinity degree, \% } \\
\left(x-\text { ray/DSC }{ }^{2}\right)\end{array}$ \\
\hline \multicolumn{7}{|c|}{ Cocatalyst MAO } \\
\hline $1-A,-$ & 0 & 951 & 6.2 & 136.0 & 172.7 & $56 / 59$ \\
\hline 2-A, 1-hexene & 0.3 & & & 128.7 & 135.4 & $45 / 46$ \\
\hline 3-A, 1-hexene & $8.0-9.0$ & 311 & 8.5 & 118.6 & 53.45 & $21 / 18$ \\
\hline 4-A, 1-octene & - & 670 & 9.2 & 130.1 & 142.8 & $51 / 49$ \\
\hline 5-A, 1-decene & 0.4 & 826 & 6.6 & 132.1 & 146.7 & $51 / 50$ \\
\hline 6-A, 1-decene & 0.7 & 660 & 6.2 & 128.3 & 135.2 & $45 / 46$ \\
\hline \multicolumn{7}{|c|}{ Cocatalyst $\mathrm{AlEt}_{2} \mathrm{Cl} / \mathrm{MgBu}_{2}$} \\
\hline $1-B,-$ & 0 & 531 & 7.6 & 131.7 & 197.0 & $61 / 67$ \\
\hline 2-B, 1-hexene & $3.5-4.0$ & 278 & 10.8 & 121.8 & 113.6 & $48 / 39$ \\
\hline 3-B, 1-hexene & $12.0-13.0$ & 64 & 8.4 & 118.0 & 36.9 & $21 / 13$ \\
\hline 4-B, 1-hexene & $20.0-22.0$ & 74 & 9.6 & 118.5 & 7.4 & amorph./ 2 \\
\hline 5-B, 1-octene & 1.7 & 396 & 16.7 & 124.9 & 126.3 & $52 / 43$ \\
\hline 6-B, 1-octene & $9.0-10.0$ & 70 & 9.7 & 118.8 & 30.1 & $10 / 10$ \\
\hline 7-B, 1-decene & 1.3 & 123 & 8.8 & 125.2 & 146.7 & $51 / 50$ \\
\hline 8-B, 1-decene & $8.0-9.0$ & 85 & 10.4 & 118.6 & 39.9 & $25 / 14$ \\
\hline
\end{tabular}

${ }^{1}$ Measurement at $10^{\circ} \mathrm{C} \cdot \mathrm{min}^{-1}$ heating rate, second melting.

${ }^{2}\left(\Delta H_{\text {fusion }} / \Delta H_{\text {fusion }}\right) \cdot 100$, where $\Delta H_{\text {fusion }}=293 \mathrm{~J} \cdot \mathrm{g}^{-1}$.

The reason for the relative inertness of the $>\mathrm{Ti}-\mathrm{C}_{2} \mathrm{H}_{5}$ group is a stronger agostic interaction between its $\beta-\mathrm{CH}_{3}$ group and the $\mathrm{Ti}$ atom compared to the agostic interaction between the $\beta-\mathrm{CH}_{2}$ group and the $\mathrm{Ti}$ atom in the $\mathrm{Ti}$ species in Reaction 2. In the presence of an a-olefin $\mathrm{CH}_{2}=\mathrm{CH}-R$ (where $R=\mathrm{C}_{4} \mathrm{H}_{9}$, etc.), the initiation $>\mathrm{Ti}-\mathrm{CH}_{2}-\mathrm{CH}_{3}$ species are partially replaced with the $>\mathrm{Ti}-\mathrm{CH}_{2}-\mathrm{CH}_{2}-\mathrm{R}$ species which insert ethylene with a rate constant comparable to $k^{\prime \prime}$ and higher than in Reaction 1):

$>\mathrm{Ti}-\mathrm{CH}_{2}-\mathrm{CH}_{2}-R+\mathrm{CH}_{2}=\mathrm{CH}_{2}-\left(k^{\prime \prime}\right) \rightarrow$ $>\mathrm{Ti}-\mathrm{CH}_{2}-\mathrm{CH}_{2}-\mathrm{CH}_{2}-\mathrm{CH}_{2}-R$

In our experiments, the correlation between an increase catalyst activity and crystallinity degree of produced products was absent. So the second exlanation of comonomer effect seems more liklely.

The binary $\mathrm{AlEt}_{2} \mathrm{Cl}-\mathrm{MgBu}_{2}$ cocatalyst is much more effective in producing a catalyst system with expressed copolymerization ability (runs of B series in Table $\mathbf{1}$ ). This cocatalyst affords the synthesis of copolymers with the $\alpha$-olefin content ranging from $\sim 3.5 z$ to over 20 $\mathrm{mol}$. \%. The copolymer yields, 1666 to $4266 \mathrm{~kg} \cdot \mathrm{mol}_{T}{ }^{-1}$, are also significantly higher than those in the experiments with MAO.
As we proposed earlier [9, 22], the efficiency of the $\mathrm{AlEt}_{2} \mathrm{Cl}-\mathrm{MgBu}_{2}$ combination as a cocatalyst is partially related to a reaction between $\mathrm{AlEt}_{2} \mathrm{Cl}$ and $\mathrm{MgBu}_{2}$ leading to the generation of highly dispersed $\mathrm{MgCl}_{2}$ with the Lewis-acidic surface:

$\mathrm{MgBu}_{2}+2 \mathrm{AlR} 2 \mathrm{Cl} \rightarrow\left[\mathrm{MgCl}_{2}\right]+2 \mathrm{AlR}_{2} \mathrm{Bu}$

An $L \mathrm{TiCl}_{2}$ complex with a bidentate ligand, such as complex $\mathbf{I}$, is alkylated to $L T i R C l$ either with $A I R_{2} C l$ itself or with $\mathrm{AlR}_{2} \mathrm{Bu}$ formed in Reaction 4 and is adsorbed on the $\mathrm{MgCl}_{2}$ surface. The adsorbed $L T i R C I$ species can be ionized with the formation of an active center, a cationic species containing the catalytically active $\mathrm{Ti}^{+}-\mathrm{C}$ bond:

$\mathbf{L T R i C l}+\left[\mathrm{MgCl}_{2}\right] \rightarrow\left[\boldsymbol{L T i}{ }^{+}-\mathrm{R}\right]_{\mathrm{ads}} /\left[\mathrm{MgCl}_{2} \cdots \mathrm{Cl}^{-}\right]$

Complex I already contains a small amount of highly dispersed $\mathrm{MgCl}_{2}$, which is formed in the process of its synthesis (see Experimental). The presence of much larger quantities of $\mathrm{MgCl}_{2}$ in all experiments involving $\mathrm{AlEt}_{2} \mathrm{Cl}-\mathrm{MgBu}_{2}$ combinations leads to catalyst systems of a superior activity.

The second possible explanation proposed in [22] to account for the high efficiency of $\mathrm{AlR}_{2} \mathrm{Cl}-\mathrm{MgR}_{2}{ }_{2}$ combinations in activating such diverse polymerization 
catalysts as metallocene complexes, standard supported Ti-based Ziegler-Natta catalysts (which already contain large fractions of highly dispersed $\mathrm{MgCl}_{2}$ ) and various multidentate complexes of transition metals (such as complex $\mathbf{I}$ in this research) is the formation of ion pairs $\left[\mathrm{MgR}^{\prime}\right]^{+}[\mathrm{A}]^{-}$and $[\mathrm{MgCl}]^{+}[\mathrm{A}]^{-}$ from $\mathrm{MgR}_{2}$ or from $\mathrm{MgR} \mathrm{Cl}^{\prime}$ (the intermediate product in Reaction 4) with $[A]^{-}=\left[R_{2} R_{2}^{\prime} A I\right]^{-}$or $\left[R_{2} R^{\prime} A I C l{ }^{\prime} A I R^{\prime} R_{2}\right]^{-}$. Such ion pairs efficiently convert mono-alkylated complexes $L T i R C I$ into active species, for example:

$$
\mathrm{LTiRCl}+\left[\mathrm{MgR}^{\prime}\right]^{+}[\mathrm{A}]^{-} \rightarrow\left[\mathrm{LTi}^{+}-\mathrm{R}\right]\left[\mathrm{A}^{-}\right]+\mathrm{MgR} \mathrm{Rl}^{\prime} \mathrm{Cl}
$$

\subsection{Comonomer Reactivity and Reaction Kinetics}

A comparison of compositions of comonomer mixtures $\left(C_{\mathrm{E}}{ }^{\text {mon }}=0.37 \mathrm{M}, C_{\mathrm{M}}{ }^{\text {mon }}\right.$ values are given in Table 1) and compositions of copolymers prepared with $\mathrm{AlEt}_{2} \mathrm{Cl}-\mathrm{MgBu}_{2}$ cocatalyst (from Table 1) affords an approximate evaluation of the average reactivity ratio $r_{1}$ :

$r_{1}=k_{\mathrm{E}-\mathrm{E}} / k_{\mathrm{E}-\mathrm{M}} \approx\left(C_{\mathrm{E}} / C_{\mathrm{M}}\right)^{\mathrm{copol} /\left(C_{\mathrm{E}} / C_{\mathrm{M}}\right)^{\mathrm{mon}}}$

where $k_{\mathrm{E}-\mathrm{E}}$ and $k_{\mathrm{E}-\mathrm{M}}$ are, respectively, the rate constants for addition of ethylene and a given a-olefin $M$ to a growing polymer chain with the last ethylene unit, $\mathrm{Ti}-\mathrm{CH}_{2}-\mathrm{CH}_{2}-$ Polymer. (Equation 7 is suitable for the $r_{1}$ evaluation only for reactions which produce copolymers with low $C_{\mathrm{M}}{ }^{\text {copol }}$ values, typically below $10 \mathrm{~mol}$. \% $[1,23]$.

$\mathrm{k}_{\mathrm{eff}} \cdot 10^{-3}, 1 \cdot(\mathrm{mol} \mathrm{Ti} \cdot \mathrm{min})^{-1}$

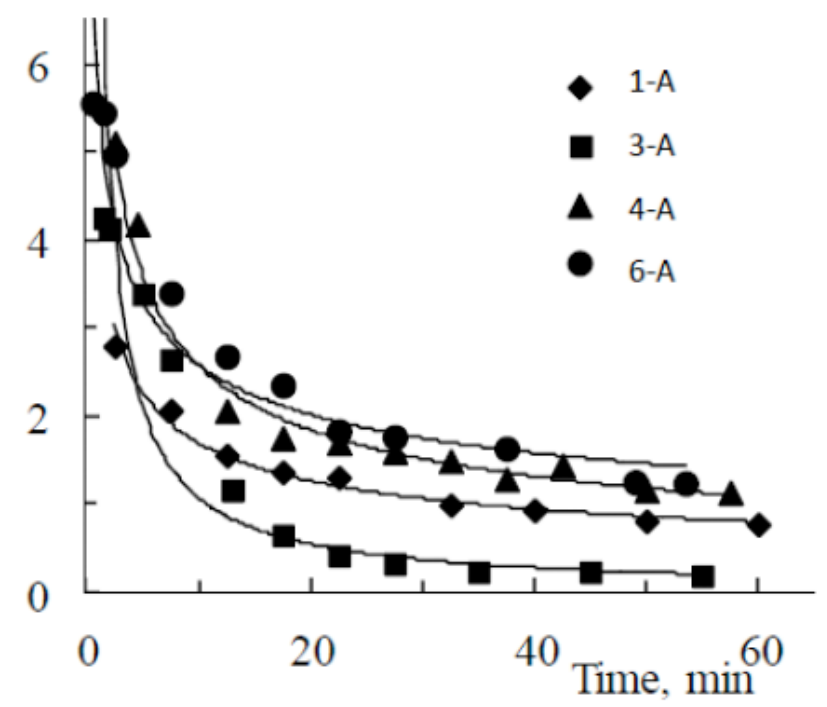

A
Monomer pair:

ethylene/1-hexene ethylene/1-octene ethylene/1-decene

$$
\begin{array}{lll}
r_{1}: 16-32 & 41-46 \quad 46-53
\end{array}
$$

As one can expect, the $r_{1}$ value is significantly higher than one (ethylene has the highest reactivity in the chain grows reaction compared to all other $\alpha$ olefins) and its value gradually increases (the relative reactivity of the olefin, $k_{\mathrm{E}-\mathrm{M}}$ vs. $k_{\mathrm{E}-\mathrm{E}}$, decreases) as the length of the linear alkyl group $R$ in the $\mathrm{CH}_{2}=\mathrm{CH} R$ olefin becomes larger. A similar effect was observed earlier in ethylene/a-olefin copolymerization reactions with heterogeneous Ziegler-Natta catalysts [24].

Catalyst systems based on complex I are very unstable under our copolymerization conditions (Figure 1). The instability is especially pronounced when the $\mathrm{AlEt}_{2} \mathrm{Cl}-\mathrm{MgBu}_{2}$ combination is used as the cocatalyst: the effective rate constant decreases approximately ten-fold, from $\sim 38,000$ to $\sim 3,900 \mathrm{I} \cdot\left(\mathrm{mol} \mathrm{Ti} \cdot \mathrm{min}^{-1}\right.$, during the first 10 minutes of the polymerization reaction.

\subsection{Molecular Weight Distribution}

All ethylene homopolymers and copolymers produced with complex I have a broad molecular weight distribution (Table 2), a consequence of the presence of several different types of active centers in the catalyst systems. Separation of GPC curves of polymer products into their Flory components (the

$$
\mathrm{k}_{\mathrm{eff}} \cdot 10^{-3}, 1 \cdot(\mathrm{mol} \mathrm{Ti} \cdot \mathrm{min})^{-1}
$$

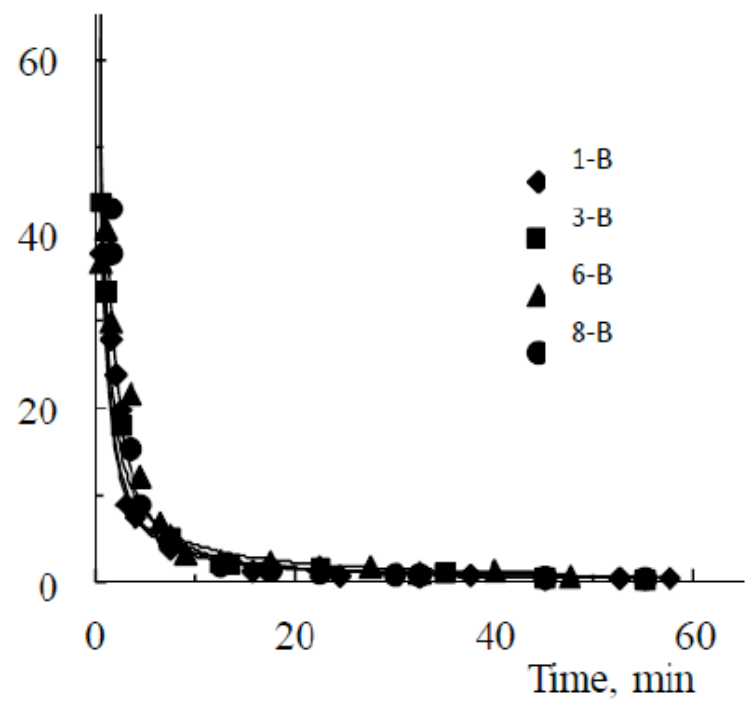

B

Figure 1: Kinetics of ethylene consumption with I - MAO (A) and I - $\mathrm{AlEt}_{2} \mathrm{Cl}-\mathrm{MgBu}_{2}(\mathbf{B})$ catalyst systems. 


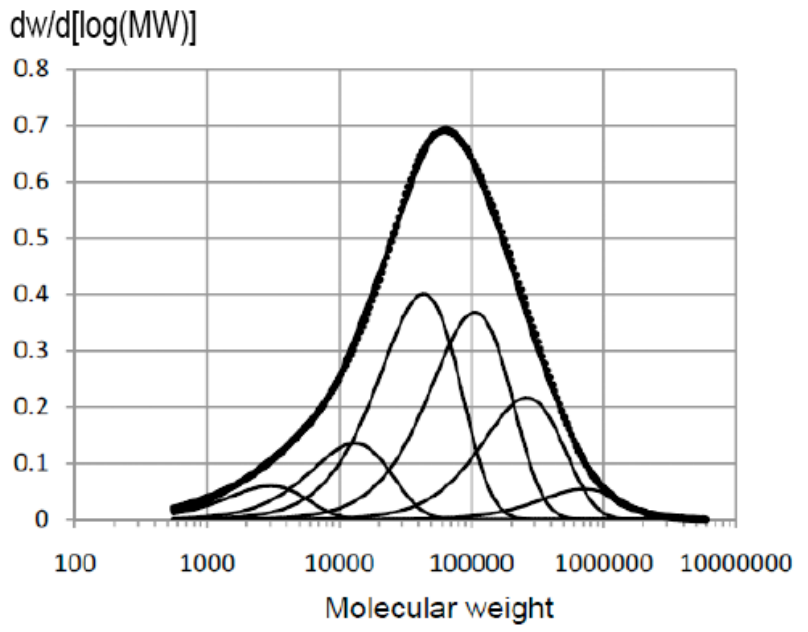

A $\mathrm{d} w / \mathrm{d}[\log (\mathrm{MW})]$

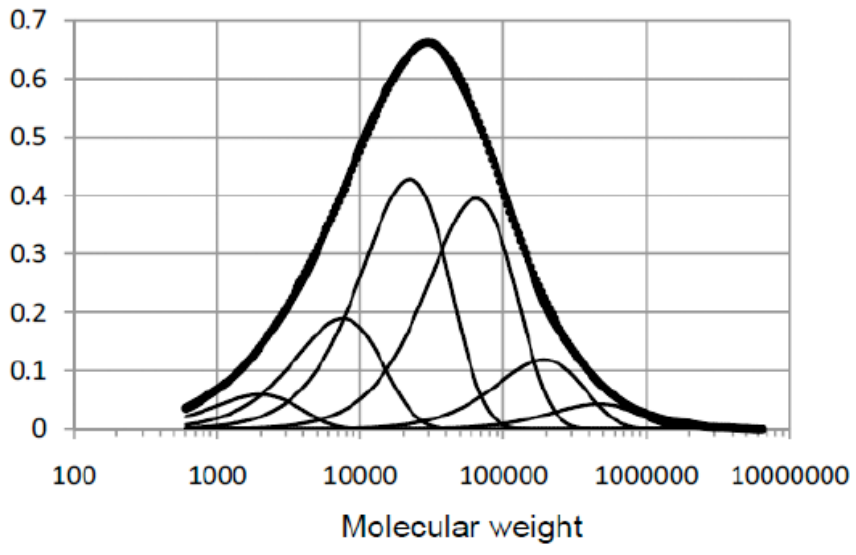

B

Figure 2: GPC curves of ethylene copolymers and their resolution into Flory components. A - ethylene/1-decene copolymer (run $7-\mathrm{B}, C_{\mathrm{M}}{ }^{\mathrm{copol}} \sim 1.3 \mathrm{~mol}$ \% \%), B - ethylene/1-hexene copolymer (run 3-B, $C_{\mathrm{M}}{ }^{{ }^{\circ o p o l}} \sim 13 \mathrm{~mol}$. \%).

Table 3: Flory Components in Ethylene/1-Hexene Copolymer Produced with Complex I Activated with MAO

\begin{tabular}{|c|c|c|c|c|}
\hline \multirow{2}{*}{$\begin{array}{c}\text { Run: } \\
C_{\mathrm{M}}^{\text {copol }} \text {, mol. \%: } \\
\text { Flory components }\end{array}$} & \multicolumn{2}{|c|}{$\begin{array}{c}1-\mathrm{A} \\
0\end{array}$} & \multicolumn{2}{|c|}{$\begin{array}{c}3-A \\
8.0-9.0\end{array}$} \\
\hline & $M_{\mathrm{w}} \cdot 10^{-5}$ & Fraction, \% & $M_{\mathrm{w}} \cdot 10^{-5}$ & Fraction, \% \\
\hline I & & & 0.08 & 2.6 \\
\hline II & 0.28 & 2.2 & 0.30 & 13.2 \\
\hline III & 0.80 & 8.6 & 0.74 & 32.2 \\
\hline IV & 2.80 & 21.6 & 2.10 & 27.8 \\
\hline$V$ & 8.90 & 46.1 & 6.00 & 17.6 \\
\hline VI & $\sim 22.0$ & 21.6 & $\sim 18.0$ & 6.6 \\
\hline Average values & \multicolumn{2}{|c|}{$\begin{array}{c}M_{\mathrm{w}}^{\mathrm{av}}=9.5 \cdot 10^{-5} \\
M_{\mathrm{w}} / M_{\mathrm{n}}=6.2\end{array}$} & \multicolumn{2}{|c|}{$\begin{array}{c}M_{\mathrm{w}}^{\mathrm{av}}=3.1 \cdot 10^{-5} \\
M_{\mathrm{w}} / M_{\mathrm{n}}=8.5\end{array}$} \\
\hline
\end{tabular}

components produced by a single type of active center in terms of its kinetic parameters [16] showed that all the polymers produced with I consist of five or six Flory components with different molecular weights. Two examples of the GPC curve resolution are shown in Figure 2 and molecular weights of the Flory components are listed in Tables $\mathbf{3}$ and $\mathbf{4}$. The contents of the Flory components with the highest molecular weights $\left(M_{\mathrm{w}} \sim 2.0-2.2 \cdot 10^{6}\right)$ in PE prepared with MAO as a cocatalyst are significantly higher than in $\mathrm{PE}$ prepared with $\mathrm{AlEt}_{2} \mathrm{Cl}-\mathrm{MgBu}_{2}, \sim 22 \%$ vs. $\sim 9 \%$. As a result, the average $M_{\mathrm{w}}$ value for the former polymer, $\sim 9.5 \cdot 10^{5}$, is significantly higher than for the latter one, $\sim 5.3 \cdot 10^{5}$. Introduction of small amounts of a-olefins invariably leads to a decrease of their average $M_{w}$ values (Tables 3 and 4). Importantly, the contents of different Flory components in the copolymers of a comparable composition do not depend on the type of the $\alpha$-olefin used in the copolymerization reactions (Table 4).

\subsection{Compositional Distribution of Copolymers}

Detailed analysis of DSC melting curves of semicrystalline polymers is a sensitive tool for determining the level of their compositional and structural uniformity. The procedure for resolution of multicomponent DSC melting curves into melting peaks of individual components was reported earlier [25]. Analysis of DSC melting curves of the ethylene/a-olefin copolymers prepared with the catalysts based on complex I shows that different copolymer components differ also with respect to their composition and the crystallinity degree. Figure 3 shows DSC curves of three polymer products produced with the $\mathbf{I}-\mathrm{AlEt}_{2} \mathrm{Cl}$ $\mathrm{MgBu}_{2}$ catalytic system. Linear polyethylene formed in run $1-\mathrm{B}$ has a narrow melting peak with the maximum at $\sim 133^{\circ} \mathrm{C}$. Both copolymers in Figure 4 have multiple melting peaks, which are especially obvious in the case of the copolymers with a high a-olefin content (Figure 4-C). 
Table 4: Flory Components in Ethylene/a-Olefin Copolymers Produced with Complex I Activated with $\mathrm{AIEt} \mathrm{Cl}_{2}-\mathrm{MgBu}_{2}$ Cocatalyst

\begin{tabular}{|c|c|c|c|c|c|c|c|c|c|c|c|c|c|c|}
\hline \multirow{2}{*}{$\begin{array}{c}\begin{array}{c}\alpha-O l e f i n: \\
C_{\mathrm{M}}^{\text {copol }}\end{array} \\
\text { mol. \%: }\end{array}$} & \multicolumn{2}{|c|}{ - } & \multicolumn{2}{|c|}{$\begin{array}{c}\text { 1-Hexene } \\
3.5-4.0\end{array}$} & \multicolumn{2}{|c|}{$\begin{array}{r}1-\text { Hexene } \\
12.0-13.0\end{array}$} & \multicolumn{2}{|c|}{$\begin{array}{l}\text { 1-Hexene } \\
20.0-22.0\end{array}$} & \multicolumn{2}{|c|}{$\begin{array}{l}\text { 1-Octene } \\
9.0-10.0\end{array}$} & \multicolumn{2}{|c|}{$\begin{array}{c}\text { 1-Decene } \\
1.3\end{array}$} & \multicolumn{2}{|c|}{$\begin{array}{c}\text { 1-Decene } \\
8.0-9.0\end{array}$} \\
\hline & $M_{\mathrm{w}} \cdot 10^{-5}$ & $\begin{array}{l}\text { Fr. } \\
\%\end{array}$ & $M_{\mathrm{w}} \cdot 10^{-5}$ & $\begin{array}{c}\text { Fr., } \\
\%\end{array}$ & $M_{w} \cdot 10^{-5}$ & $\begin{array}{c}\text { Fr. } \\
\%\end{array}$ & $M_{\mathrm{w}} \cdot 10^{-5}$ & $\begin{array}{c}\text { Fr., } \\
\%\end{array}$ & $M_{\mathrm{w}} \cdot 10^{-5}$ & $\begin{array}{c}\text { Fr. } \\
\%\end{array}$ & $M_{w} \cdot 10^{-5}$ & $\begin{array}{c}\text { Fr., } \\
\%\end{array}$ & $M_{\mathrm{w}} \cdot 10^{-5}$ & $\begin{array}{c}\text { Fr., } \\
\%\end{array}$ \\
\hline I & 0.11 & 2.4 & 0.055 & 3.5 & 0.02 & 4.8 & 0.02 & 2.6 & 0.019 & 4.8 & 0.03 & 4.8 & 0.019 & 3.5 \\
\hline II & 0.50 & 9.1 & 0.20 & 11.4 & 0.075 & 15.4 & 0.075 & 14.0 & 0.07 & 17.3 & 0.13 & 11.0 & 0.06 & 15.0 \\
\hline III & 1.40 & 32.5 & 0.55 & 31.9 & 0.22 & 34.6 & 0.024 & 35.1 & 0.22 & 35.5 & 0.43 & 32.5 & 0.22 & 33.9 \\
\hline IV & 3.90 & 28.2 & 1.60 & 27.5 & 0.64 & 32.0 & 0.64 & 32.9 & 0.64 & 27.3 & 1.10 & 29.8 & 0.64 & 28.2 \\
\hline$V$ & $\sim 10.0$ & 18.7 & 4.80 & 18.3 & 1.90 & 9.6 & 1.80 & 11.0 & 1.80 & 10.8 & 2.60 & 17.5 & 1.8 & 12.8 \\
\hline VI & 20.0 & 9.1 & $\sim 17.0$ & 7.4 & 4.60 & 3.5 & 5.40 & 4.4 & 5.40 & 4.3 & 7.00 & 4.4 & 5.4 & 6.6 \\
\hline $\begin{array}{l}\text { Average } \\
\text { values }\end{array}$ & \multicolumn{2}{|c|}{$\begin{array}{c}M_{\mathrm{w}}^{\mathrm{av}}= \\
5.31 \cdot 10^{-5} ; \\
M_{\mathrm{w}} / M_{\mathrm{n}}=7.6\end{array}$} & \multicolumn{2}{|c|}{$\begin{array}{c}M_{\mathrm{w}}^{\mathrm{av}}= \\
2.78 \cdot 10^{-5} \\
M_{\mathrm{w}} / M_{\mathrm{n}}=10.8\end{array}$} & \multicolumn{2}{|c|}{$\begin{array}{c}M_{\mathrm{w}}^{\mathrm{av}}= \\
0.63 \cdot 10^{-5} ; \\
M_{\mathrm{w}} / M_{\mathrm{n}}=8.4\end{array}$} & \multicolumn{2}{|c|}{$\begin{array}{c}M_{\mathrm{w}}^{\mathrm{av}}= \\
0.74 \cdot 10^{-5} ; \\
M_{\mathrm{w}} / M_{\mathrm{n}}=7.7\end{array}$} & \multicolumn{2}{|c|}{$\begin{array}{c}M_{\mathrm{w}}^{\mathrm{av}}= \\
0.70 \cdot 10^{-5} ; \\
M_{\mathrm{w}} / M_{\mathrm{n}}=9.7\end{array}$} & \multicolumn{2}{|c|}{$\begin{array}{c}M_{\mathrm{w}}^{\mathrm{av}}= \\
1.23 \cdot 10^{-5} ; \\
M_{\mathrm{w}} / M_{\mathrm{n}}=8.8\end{array}$} & \multicolumn{2}{|c|}{$\begin{array}{c}M_{\mathrm{w}}^{\mathrm{av}}= \\
085 \cdot 10^{-5} \\
M_{\mathrm{w}} / M_{\mathrm{n}}=10.4\end{array}$} \\
\hline
\end{tabular}

\section{$\mathrm{dW} / \mathrm{d}[\log (\mathrm{MW})]$}

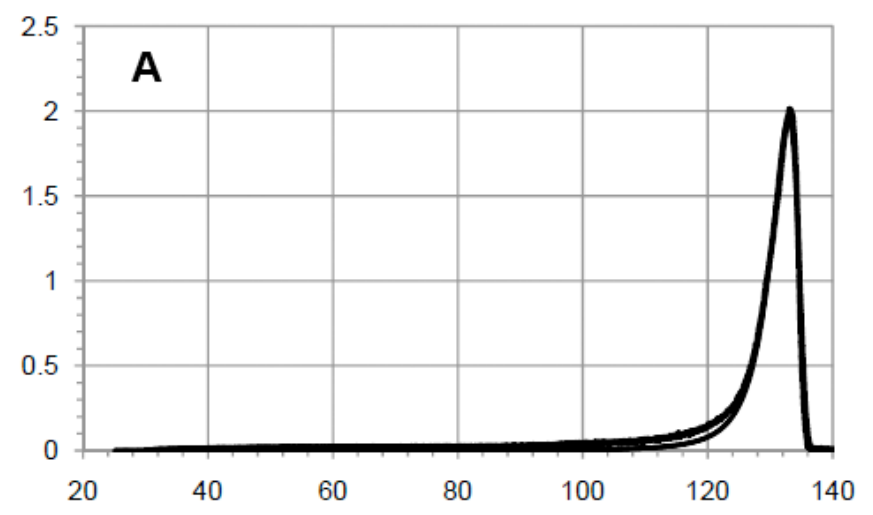

Temperature, ${ }^{\circ} \mathrm{C}$

\section{$\mathrm{dW} / \mathrm{d}[\log (\mathrm{MW})]$}

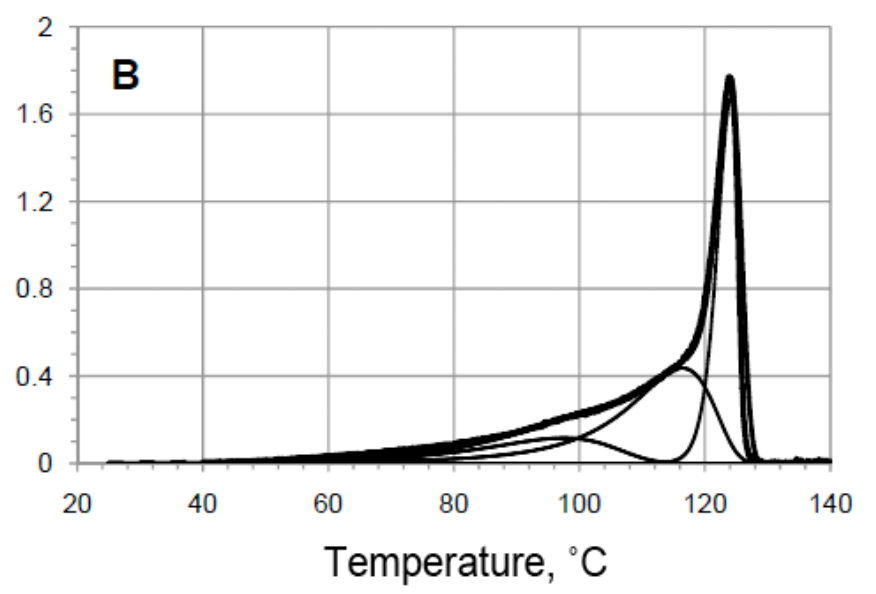

$\mathrm{dW} / \mathrm{d}[\log (\mathrm{MW})]$

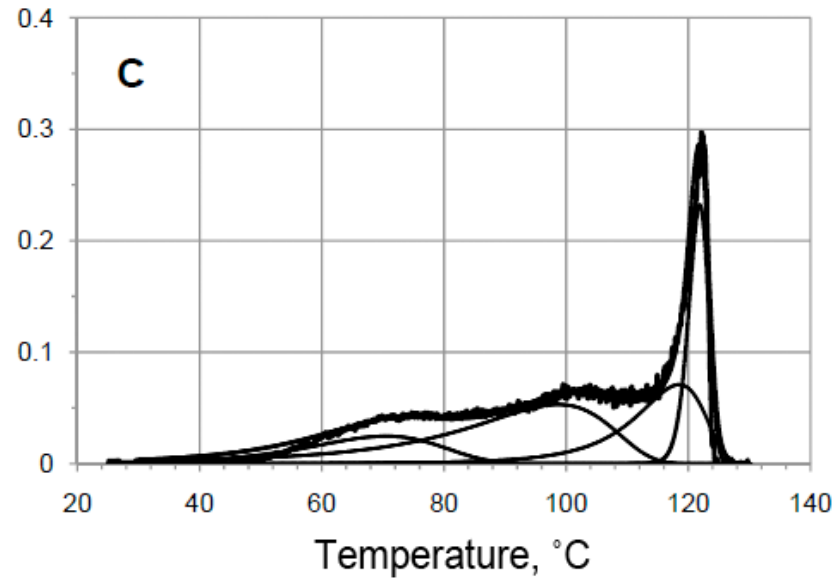

Figure 3: DSC melting curves $\left(2{ }^{\circ} \mathrm{C} \cdot \mathrm{min}^{-1}\right.$ heating rate) and their resolution into melting curves of individual crystalline components. A - Ethylene homopolymer (run 1-B), B - ethylene/1-hexene copolymer (run 2-B, $C_{M}{ }^{\text {copol }} \sim 3.5 \mathrm{~mol}$. \%), C ethylene/1-decene copolymer (run 8-B, $C_{\mathrm{M}}{ }^{\text {copol }} \sim 8 \mathrm{~mol}$. \%). 


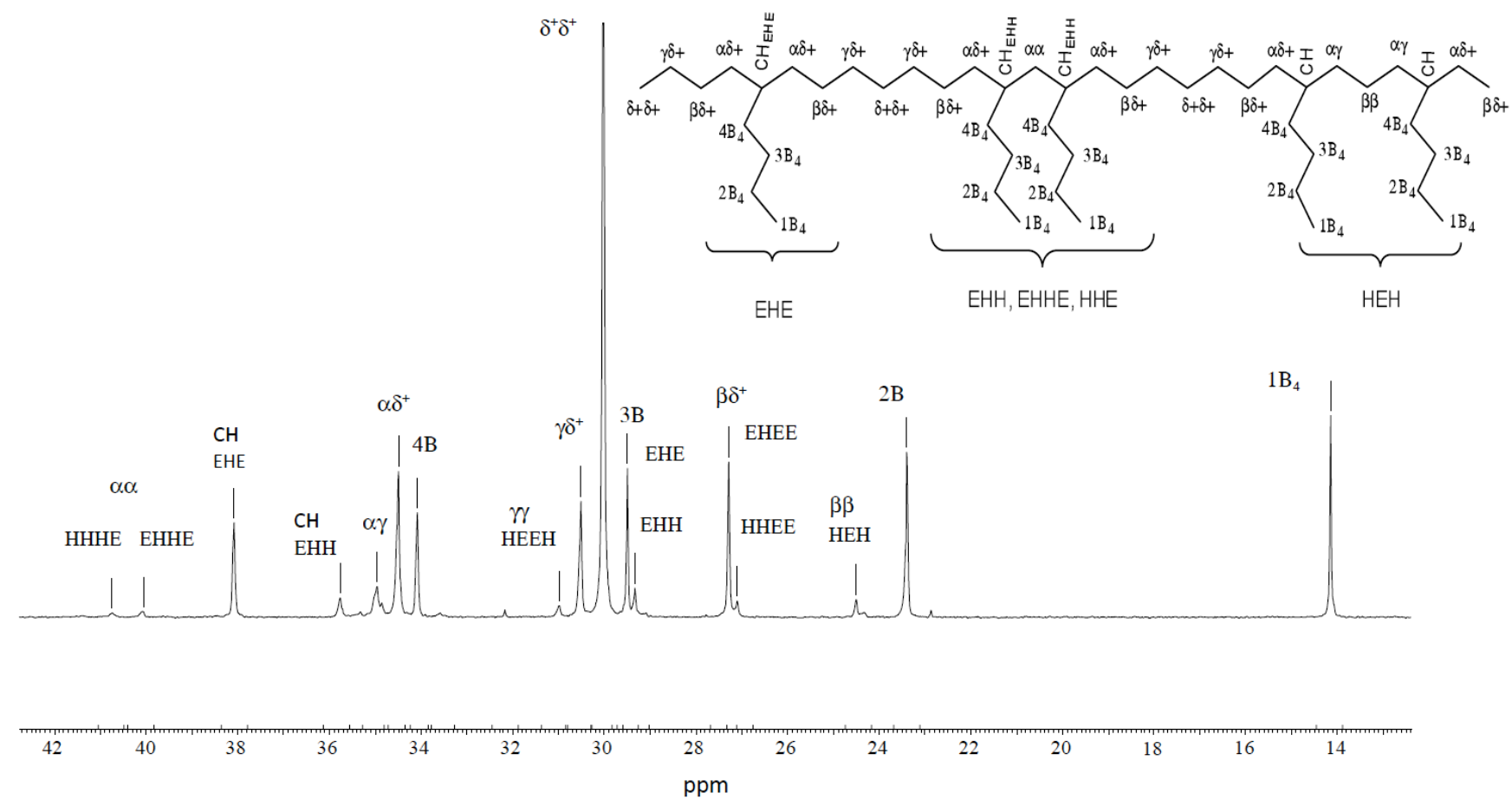

Figure 4: ${ }^{13} \mathrm{C}$ NMR spectrum of ethylene/1-hexene copolymer produced in run 3-B and the signal assignment.

The results of the DSC curve resolution are presented in Table $\mathbf{5}$. They can be rationalized in the following way:

1. The I- $\mathrm{AlEt}_{2} \mathrm{Cl}-\mathrm{MgBu}_{2}$ system has four sets of active centers with different ability to copolymerize a-olefins with ethylene with the formation of semi-crystalline products (the only polymer material detectable by DSC).

2. The first group of the centers generates copolymer components with low $\alpha$ olefin content. These materials produce sharp melting peaks at the highest temperatures, from $\sim 133{ }^{\circ} \mathrm{C}$ in the homopolymer to $\sim 122{ }^{\circ} \mathrm{C}$ in the copolymer with the average $C_{\mathrm{M}}{ }^{\text {copol }}$ value of $\sim 8-9$ mol. \%.Judging by the composition of these fractions, the reactivity ratio $r_{1}$ for these centers is high, $\sim 210$.

3. Two groups of the centers, centers 3 and 4, produce copolymers with much higher a-olefin contents. Their melting points are significantly lower and the respective peaks are broader. The reactivity ratio for center 3 is $\sim 95$ and that for center 4 is $\sim 65$.

4. Centers 2 have a medium-to-low ability to copolymerize $\alpha$-olefins with ethylene, $r_{1} \sim 160$. The melting peak of this component in the copolymer with the average $C_{\mathrm{M}}{ }^{\text {copol }}$ value of 3.5-
4.0 mol. \% produced in run 2-B merges with the melting peak of component 1 .

5. Table 5 reports two values of "fractions". The first number gives the fraction with respect to the total crystalline material. Because copolymer components 1 and 2 are always more crystalline than components 3 and 4 , this fraction, which is proportional to the areas under melting peaks, overemphasizes the productivity of the respective active centers. The second fraction gives an approximate estimation of the combined relative yield of both the crystalline and the amorphous parts of the copolymer components generated by each type of active center. This estimation is based on the relationship between the composition of ethylene/a-olefin copolymers and their crystallinity level reported earlier [25]. The results for the copolymers in Table $\mathbf{5}$ indicate that relative productivity of the four types of the centers does not depend much on the presence of an olefin in the monomer mixture. The introduction of the a-olefin merely reveals the presence of different types of the centers, which is unobservable in ethylene homopolymerization reactions when all the centers produce the same linear polymer chains.

6. A comparison of the average $\alpha$-olefin content in the copolymers in Table 5 and the olefin content in different crystalline fractions suggests that the 
Table 5: Results of the DSC Curve Resolution for Four Polymer Products

\begin{tabular}{|c|c|c|c|c|}
\hline Polymer: & $\begin{array}{c}\text { PE } \\
\text { (run1-B) }\end{array}$ & $\begin{array}{c}\text { Ethylene/1-hexene } \\
\text { copol. (run 2-B) } \\
C_{\mathrm{Hex}}{ }^{\mathrm{av}}=3.5-4.0 \mathrm{~mol} . \%\end{array}$ & 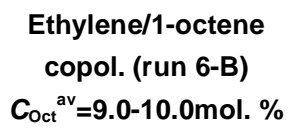 & $\begin{array}{c}\text { Ethylene/1-decene } \\
\text { copol. (run 8-B) } \\
C_{\text {Dec }}{ }^{a v}=8.0-9.0 \mathrm{~mol} . \%\end{array}$ \\
\hline $\mathrm{T}_{\mathrm{m}}(1),{ }^{\circ} \mathrm{C}$ & 132.9 & 124.1 & 121.9 & 121.9 \\
\hline$C_{\mathrm{M}}{ }^{\text {copol }}(1)$, mol. $\%$ & 0 & 1.7 & 1.9 & 1.9 \\
\hline Fraction (1) & 1 & $0.41 / 0.29$ & $0.19 / 0.08$ & $0.21 / 0.08$ \\
\hline $\mathrm{T}_{\mathrm{m}}(2),{ }^{\circ} \mathrm{C}$ & & 116.6 & 118.5 & 118.5 \\
\hline$C_{\mathrm{M}}{ }^{\mathrm{copol}}(2), \mathrm{mol} . \%$ & & 2.8 & 2.5 & 2.5 \\
\hline Fraction (2) & & $0.42 / 0.40$ & $0.29 / 0.15$ & $0.24 / 0.11$ \\
\hline $\mathrm{T}_{\mathrm{m}}(3),{ }^{\circ} \mathrm{C}$ & & 97.5 & 98.8 & 98.7 \\
\hline$C_{\mathrm{M}}{ }^{\mathrm{copol}}(3), \mathrm{mol} . \%$ & & 4.7 & 4.8 & 4.8 \\
\hline Fraction (3) & & $0.17 / 0.31$ & $0.40 / 0.44$ & $0.40 / 0.42$ \\
\hline $\mathrm{T}_{\mathrm{m}}(4),{ }^{\circ} \mathrm{C}$ & & & 70.4 & 79.5 \\
\hline$C_{\mathrm{M}}{ }^{\mathrm{copol}}(4), \mathrm{mol} . \%$ & & & $\sim 7.0$ & $\sim 7.0$ \\
\hline Fraction (4) & & & $0.12 / 0.33$ & $0.15 / 0.38$ \\
\hline
\end{tabular}

copolymer mixtures contain not only partially crystalline fractions but also completely amorphous components which are not observable by DSC.

\subsection{Microstructure of Copolymer Chains}

Figure 4 shows the ${ }^{13} \mathrm{C}$ NMR spectrum of the copolymer produced in run $3-\mathrm{B}$. The signals in the spectrum are assigned according to [14]. Monomer units in the chains derived from 1-hexene units $(H)$ are predominantly isolated in the copolymer chain as "EHE' ${ }^{\cdots}$ sequences [large signals of $\mathrm{CH}(\mathrm{EHE})$ and $3 \mathrm{~B}(\mathrm{EHE})$ triads, $\beta, \delta^{+}-\mathrm{CH}_{2}(\mathrm{EHEE})$ tetrad]. Only a small fraction of the hexene units is positioned in $\mathrm{HH}$ diads $\left[\alpha, \alpha-\mathrm{CH}_{2}\right.$ (EHHE) and $\beta, \delta^{+}-\mathrm{CH}_{2}$ (HHEE) tetrads, $\mathrm{CH}(\mathrm{EHH})$ and $3 \mathrm{~B}(\mathrm{EHH})$ triads].

The ability of active centers to alternate monomer units $E$ and $M$ in $E / M$ copolymer chain is usually represented by the product of two reactivity ratios, $r_{1} r_{2}$ $[1,23]$. When $r_{1} r_{2}=1$, the relative probability of finding a given monomer unit in the copolymer chain is governed only by its reactivity and the comonomer concentration but does not depend on the nature of the preceding monomer unit in the chain. Such copolymers are called random. If $r_{1} r_{2}<1$, the copolymerization catalyst has a tendency to alternate monomer units in copolymer chains and, at the limit, if the $r_{2}=k_{\mathrm{M}-\mathrm{M}} / k_{\mathrm{M}-\mathrm{E}}=$ 0 , all the a-olefin units are isolated in the chains as 'EME ${ }^{\cdots}$ sequences. In the opposite situation, if $r_{1} r_{2}>1$, the copolymerization catalyst has a tendency to produce blocks of the same monomer units.
${ }^{13} \mathrm{C}$ NMR spectra of are the most sensitive tool for the evaluation of the $r_{1} r_{2}$ value, for example by comparing relative intensities of the signals of $\alpha$-olefin blocks, EMM and EMME, vs. the signal of isolated olefin units, EME, or that of the isolated ethylene unit, MEM. Necessary expressions for the fractions of [MME], [EMME], [EME] and [MEM] as functions of copolymer composition and the $r_{1} r_{2}$ value are known from the literature $[1,19]$. The [EMME]/[MEM] and [MME]/[MEM] ratios are especially suitable for the $r_{1} r_{2}$ evaluation because these ratios are relatively insensitive to copolymer composition. Statistical expressions 'for these two ratios, although cumbersome, provide explicit relationships containing two parameters, $r_{1} r_{2}$ and the copolymer composition ratio $f=C_{\mathrm{E}}{ }^{\text {copol }} / C_{\mathrm{M}}{ }^{\text {copol }}=\left(100-C_{\mathrm{M}}{ }^{\text {copol }}\right) / C_{\mathrm{M}}{ }^{\text {copol }}$ :

$[\mathrm{EMME}] /[\mathrm{MEM}]=r_{1} r_{2} \cdot f /\left(r_{1} r_{2}+0.5 \cdot\left\{f-1+\left[(f-1)^{2}+\right.\right.\right.$ $\left.\left.\left.4 \cdot r_{1} r_{2} \cdot f\right]^{0.5}\right\}\right)$

$[\mathrm{MME}] /[\mathrm{MEM}]=2 \cdot r_{1} r_{2} \cdot f /\left(0.5 \cdot\left\{f-1+\left[(f-1)^{2}+4 \cdot r_{1} r_{2} \cdot f\right]^{0.5}\right\}\right.$

In the case of the ethylene/1-hexene copolymer with $C_{\mathrm{M}}{ }^{\text {copol }} \sim 12 \mathrm{~mol}$. \% produced in run 3-B (Figure 4) the [EMME]/[MEM] ratio is 0.49 and $[\mathrm{MME}] /[\mathrm{MEM}]=1.08$. Estimations with Eqs. 8 and 9 show that there ratios correspond to the $r_{1} r_{2}$ value in the 0.4-0.5 range. The ${ }^{13} \mathrm{C}$ NMR spectrum of the ethylene/1-octene copolymer prepared in run $6-\mathrm{B}\left(C_{\mathrm{M}}{ }^{\text {copol }} \sim 10 \mathrm{~mol}\right.$. \%, NMR data) gives $[\mathrm{MME}] /[\mathrm{MEM}] \sim 0.90$, which also corresponds to $r_{1} r_{2} \sim 0.4$. Thus the active centers in the I- $\mathrm{AlEt}_{2} \mathrm{Cl}-$ $\mathrm{MgBu}_{2}$ catalytic system which has the highest ability to 
copolymerize $\alpha$-olefins with ethylene (such as centers 3 and 4 in Table 5) show a significant tendency to alternate monomer units in the copolymer chains. This tendency manifests itself in lower fractions of MM diads and the practical absence of MMM triads compared to those expected in purely random copolymers of the same composition.

A very small signal of the $\left(\mathrm{CH}_{2}\right)-\underline{C} \mathrm{H}_{2}$ atom in the $\mathrm{CH}\left(\mathrm{C}_{4} \mathrm{H}_{9}\right)-\mathrm{CH}_{2}-\underline{\mathrm{C}} \mathrm{H}_{2}-\mathrm{CH}\left(\mathrm{C}_{4} \mathrm{H}_{9}\right)-$ sequence at 22.7 ppm in the spectrum in Figure 6 indicates that, on rear occasions, 1-hexene units can enter copolymer chains in the secondary orientation, as shown in Reactions 10 and 11:

$$
\begin{aligned}
& \text { Ti-CH } \mathrm{CH}_{2}-\mathrm{CHR}-\mathrm{CH}_{2}-\mathrm{CH}_{2}-\text { Polymer }+\mathbf{C H R}=\mathbf{C H}_{\mathbf{2}} \rightarrow \\
& \text { Ti-CHR-CH } \mathbf{C H}_{2}-\mathrm{CH}_{2}-\mathrm{CHR}-\mathrm{CH}_{2}-\mathrm{CH}_{2}-\text { Polymer }
\end{aligned}
$$

or

$$
\begin{aligned}
& \text { Ti-CHR- } \mathrm{CH}_{2}-\mathrm{CH}_{2}-\mathrm{CH}_{2}-\text { Polymer }+\mathrm{CH}_{2}=\mathrm{CH}_{2} \rightarrow \\
& \mathrm{Ti}-\mathrm{CH}_{2}-\mathrm{CH}_{2}-\mathrm{CHR}-\mathrm{CH}_{2}-\mathrm{CH}_{2}-\mathrm{CH}_{2}-\mathrm{Polymer} \rightarrow \\
& \left(+\mathrm{CH}_{2}=\mathrm{CHR}\right) \rightarrow \\
& \mathrm{Ti}-\mathrm{CH}_{2}-\mathrm{CHR}-\mathrm{CH}_{2}-\mathrm{CH}_{2}-\mathbf{C H R}-\mathrm{CH}_{2}-\mathrm{CH}_{2}-\mathrm{CH}_{2}-\text { Polymer }
\end{aligned}
$$

\section{CONCLUSIONS}

1. Complex I with a bidentate saligenin-type ligand reacts with two types of organometallic cocatalysts, MAO and a combination of $\mathrm{AlEt}_{2} \mathrm{Cl}$ and $\mathrm{MgBu}_{2}$ at $[\mathrm{Al}] /[\mathrm{Mg}]_{\mathrm{mol}}>3$ with the formation of ethylene/a-olefin copolymerization catalysts.

2. Ability of the $\mathbf{I}-\mathrm{AlEt}_{2} \mathrm{Cl}-\mathrm{MgBu}_{2}$ system to copolymerize a-olefins with ethylene is superior to that of the I - MAO system.

3. Reactivity of a-olefins in copolymerization reactions with ethylene decreases in the raw: 1hexene>1-octene>1-decene.

4. Both catalyst systems, I - MAO and I - $\mathrm{AlEt}_{2} \mathrm{Cl}-$ $\mathrm{MgBu}_{2}$, are multi-center catalysts, they contain active centers that greatly differs both in the average molecular weights and in composition of the copolymer molecules they produce.

5. Active centers in both catalytic systems show significant tendency to alternate monomer units in copolymer chains.

\section{ACKNOWLEDGEMENTS}

We are grateful to Dr. K. P. Brylyakov (Boreskov Institute of Catalysis, Russian Academy of Sciences,
Novosibirsk, Russia) for recording ${ }^{13} \mathrm{C}$ NMR spectra of polymer samples and to Dr. E. O. Perepelitsyna (Institute of Problems of Chemical Physics, Russian Academy of Sciences, Chernogolovka, Moscow region, Russia). This work was supported by Russian Foundation of Basic Research, projects 13-03-00296 and 13-03 -00948.

\section{REFERENCES}

[1] Krentsel BA, Kissin YV, Kleiner VI, Stotskaya SS. Polymers and Copolymers of Higher a-Olefins. New York: Hanser Publishers; 1997 [chapter 8].

[2] Peacock AJ. Handbook of Polyethylene: Structures, Properties, and Applications. New York: Marcel Dekker 2000; p. 123.

[3] (a) Oakes DCH, Gibson VC, White AJP, Williams DJ. Highly active titanium-based olefin polymerization catalysts supported by bidentate phenoxyamide ligands. Inorg Chem 2006; 45: 3476-7.

http://dx.doi.org/10.1021/ic060146k

(b) Gao ML, Gu YF, Wang $\mathrm{C}$, et al. Ethylene homopolymerization and copolymerization with $\alpha$-olefins catalyzed by titanium complexes bearing [O-NSR] tridentate ligands. J Mol Catal A: Chem 2008; 292: 62-6. http://dx.doi.org/10.1016/j.molcata.2008.06.006

(c) Ma L, Wang $\mathrm{H}$, Yi J, Huang Q, Gao K, Yang W. Copolymerization of ethylene with 1-hexene promoted by novel multi-chelated non-metallocene complexes with imine bridged imidazole ligand. J Polym Sci: Polym Chem 2010; 48(Pt A): 417-24.

[4] Chum PS, Swogger KW. Olefin polymer technologiesHistory and recent progress at The Dow Chemical Company. Prog Polym Sci 2008; 33: 797-819.

http://dx.doi.org/10.1016/j.progpolymsci.2008.05.003

[5] Arriola DJ, Carnahan EM, Hustad PD, Kuhlman RL, Wenzel TT. Catalytic production of olefin block copolymers via chain shuttling polymerization. Science 2006; 312: 714-8. http://dx.doi.org/10.1126/science.1125268

[6] (a) Park S, Han Y, Kim SK, Lee J, Kim HK, Do Y. Non-Cp type homogeneous catalytic systems for olefin polymerization. J Organomet Chem 2004; 689: 4263-76.

(b) Furuyama R, Mitani M, Mohri JI, Mori R, Tanaka H, Fujita T. Ethylene/higher a-olefin copolymerization behavior of fluorinated bis(phenoxy-imine)titanium complexes with methylalumoxane: synthesis of new polyethylene-based block copolymers. Macromolecules 2005; 38: 1546-52. http://dx.doi.org/10.1021/ma0481104

(c) Senda T, Hanaoka H, Okado Y, Oda Y, Tsurugi H, Mashima K. Titanium complexes of silicon-bridged cyclopentadienyl-phenoxy ligands modified with fusedthiophene: synthesis, characterization, and their catalytic performance in copolymerization of ethylene and 1-hexene. Organometallics 2009; 28: 6915-26.

http://dx.doi.org/10.1021/om900853q

(d) Kakinuki K, Fujiki M, Nomura K. Copolymerization of ethylene with $\alpha$-olefins containing various substituents catalyzed by half-titanocenes: factors affecting the monomer reactivities. Macromolecules 2009; 42: 4585-95. http://dx.doi.org/10.1021/ma900576v

(e) Itagaki K, Hasumi S, Fujiki M, Nomura K. Ethylene polymerization and ethylene/1-octene copolymerization using group 4 half-metallocenes containing aryloxo ligands, $\mathrm{Cp}^{*} \mathrm{MCl}$ (OAr) [M = Ti, Zr, Hf; $\mathrm{Ar}=\mathrm{O}-2,6-\mathrm{R} 2 \mathrm{C} 6 \mathrm{H} 3, \mathrm{R}=\mathrm{tBu}$, $\mathrm{Ph}$-MAO catalyst systems. J Mol Catal A: Chem 2009; 303: $102-9$

http://dx.doi.org/10.1016/j.molcata.2009.01.001 
[7] (a) Salata MR, Marks TJ. Catalyst nuclearity effects in olefin polymerization. enhanced activity and comonomer enchainment in ethylene + olefin copolymerizations mediated by bimetallic group 4 phenoxyiminato catalysts. Macromolecules 2009; 42: 1920-33. http://dx.doi.org/10.1021/ma8020745

(b) Boussie TR, Diamond GM, Goh C, et al. A fully integrated high-throughput screening methodology for the discovery of new polyolefin catalysts: discovery of a new class of high temperature single-site group (IV) copolymerization catalysts. J Am Chem Soc 2003; 125: 4306-17.

http://dx.doi.org/10.1021/ja020868k

(c) Hanaoka H, Hino T, Nabika $M$, et al. Synthesis and characterization of titanium alkyl, oxo, and diene complexes bearing a SiMe2-bridged phenoxy-cyclopentadienyl ligand and their catalytic performance for copolymerization of ethylene and 1-hexene. J Organomet Chem 2007; 692: 4717-24.

http://dx.doi.org/10.1016/j.jorganchem.2007.06.012

(d) Nomura K, Oya K, Komatsu T, Imanishi Y. Effect of the cyclopentadienyl fragment on monomer reactivities and monomer sequence distributions in ethylene/a-olefin copolymerization by a nonbridged (cyclopentadienyl)(aryloxy) titanium(IV) complex-MAO catalyst system. Macromolecules 2000; 33: 3187-9. http://dx.doi.org/10.1021/ma000317

[8] Hayatifar M, Pampaloni G, Bernazzani L, Capacchione C, Kissin YV, Galletti AMR. A new post-metallocene catalyst for alkene polymerization: copolymerization of ethylene and 1hexene with titanium complexes bearing N,Ndialkylcarbamato ligands. Polym Int 2014; 63: 560-7.

http://dx.doi.org/10.1002/pi.4558

[9] Rishina LA, Lalayan SS, Gagieva SC, Tuskaev VA, Perepelytsyna EO, Kissin YV. Polymer 2013; 54: 6526-35. http://dx.doi.org/10.1016/j.polymer.2013.09.052

[10] (a) Kissin YV, Mink RI, Brandolini AJ, Nowlin TE. AlR2Cl/MgR2 combinations as universal cocatalysts for Ziegler-Natta, metallocene, and post-metallocene catalysts. J Polym Sci Polym Chem 2009; 47: 3271-85. http://dx.doi.org/10.1002/pola.23391

(b) Kissin YV, Nowlin TE, Mink RI, Brandolini AJ. A new cocatalyst for metallocene complexes in olefin polymerization. Macromolecules 2000; 33: 4599-601. http://dx.doi.org/10.1021/ma992047e

[11] Rishina LA, Galashina NM, Gagieva SC, Tuskaev VA, Kissin YV. Cocatalyst effect in propylene polymerization reactions with post-metallocene catalysts. Eur Polym J 2013; 49: 14755.

http://dx.doi.org/10.1016/j.eurpolymj.2012.10.018

[12] Rishina LA, Lalayan SS, Galashina NM, Perepelytsyna EO, Medintseva TI, Kissin YV. Polymerization of linear higher aolefins with a modified Ziegler catalyst. Polym Sci Ser B 2014; 56: 25-30.

http://dx.doi.org/10.1134/S1560090414010096

[13] Dyachenko VI, Galakhov MV, Kolomiets AF, Fokin AV. Steric effects of ortho substituents in reactions of phenols and phenolates with polyfluoroketones. Bull Acad Sci USSR Div Chem Sci 1989; 38: 831-6.

http://dx.doi.org/10.1007/BF00953301

[14] Hsieh ET, Randall JC. Monomer sequence distributions in ethylene-1-hexene copolymers. Macromolecules 1982; 15: 1402-6.

http://dx.doi.org/10.1021/ma00233a036

[15] Nowlin TE, Kissin YV, Wagner KP. High activity ZieglerNatta catalysts for the preparation of ethylene copolymers. $J$ Polym Sci: Polym Chem (Pt A) 1988; 26: 755-64. http://dx.doi.org/10.1002/pola.1988.080260307

[16] Kissin YV. Molecular weight distributions of linear polymers: Detailed analysis from GPC data. J Polym Sci: Polym Chem (Pt A) 1995; 33: 227-37. http://dx.doi.org/10.1002/pola.1995.080330205

[17] Kissin YV, Nowlin TE, Mink RI, Brandolini AJ. Kinetics and mechanism of ethylene homopolymerization and copolymerization reactions with heterogeneous Ti-based Ziegler-Natta catalysts. Topics Catal 1999; 7: 69-98. http://dx.doi.org/10.1023/A:1019199330327

[18] Kissin YV, Mink RI, Nowlin TE. Ethylene polymerization reactions with Ziegler-Natta catalysts. I. Ethylene polymerization kinetics and kinetic mechanism. J Polym Sci: Polym Chem (Pt A) 1999; 37: 4255-72. http://dx.doi.org/10.1002/(SICl)10990518(19991201)37:23<4255::AID-POLA2>3.0.CO;2-H

[19] Kissin YV. Alkene Polymerization Reactions with Transition Metal Catalysts. Amsterdam: Elsevier 2008 [chapter 5].

[20] Kissin YV, Nowlin TE, Mink RI, Brandolini AJ. In Metalorganic Catalysts for Synthesis and Polymerization. Kaminsky W, ed. Berlin:Springer 1999; p. 60. http://dx.doi.org/10.1007/978-3-642-60178-1 6

[21] Kissin YV, Nowlin TE, Mink RI, Brandolini AJ. Ethylene polymerization reactions with Ziegler-Natta catalysts. III. Chain-end structures and polymerization mechanism. J Polym Sci: Polym Chem (Pt A) 1999; 37: 4281-94. http://dx.doi.org/10.1002/(SICI)10990518(19991201)37:23<4281::AID-POLA4>3.0.CO;2-6

[22] Rishina LA, Galashina NM, Gagieva SC, Tuskaev VA, Kissin YV. Polymerization of olefins catalyzed by a dichloride complex of titanium with a dioxolane dicarbonate ligand: The promoting effect of $\mathrm{LiCl}$ and $\mathrm{MgCl}_{2}$. Polym Sci (Ser B) 2011; 53: $42-51$. http://dx.doi.org/10.1134/S1560090411020072

[23] Ref 19B [chapter 3].

[24] Kissin YV, Beach DL. Copolymerization of ethylene with higher linear a-olefins-reactivity ratios. J Polym Sci Polym Chem Ed 1984; 22: 333-40.

http://dx.doi.org/10.1002/pol.1984.170220206

[25] Kissin YV. Modeling differential scanning calorimetry melting curves of ethylene/a-olefin copolymers. J Polym Sci: Polym Phys (Pt B) 2011; 49: 195-205. http://dx.doi.org/10.1002/polb.22164 